Obere Extremität 2020 $\cdot 15: 122-129$

https://doi.org/10.1007/s11678-019-0531-3

Received: 29 March 2019

Accepted: 3 July 2019

Published online: 1 August 2019

(c) The Author(s) 2019

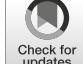

\author{
Martin Eigenschink ${ }^{1,2,3} \cdot$ Leo Pauzenberger ${ }^{1,3,4} \cdot$ Brenda Laky $^{3} \cdot$ Werner Anderl ${ }^{1,3}$ \\ Roman C. Ostermann ${ }^{1,3} \cdot$ Philipp R. Heuberer ${ }^{1,3,5}$ \\ 'Vienna Shoulder \& Sports Clinic, Vienna, Austria \\ ${ }^{2}$ AUVA Trauma Center Meidling, Vienna, Austria \\ ${ }^{3}$ Austrian Research Group for Regenerative and Orthopedic Medicine (AURROM), Vienna, Austria \\ ${ }^{4}$ Sports Surgery Clinic, Dublin, Ireland \\ ${ }^{5}$ Health Pi, Vienna, Austria
}

\title{
Arthroscopic superior capsular reconstruction using a human dermal allograft in patients with and without preoperative pseudoparalysis
}

\section{Introduction}

Irreparable posterosuperior rotator cuff ruptures in the young patient remain a challenging clinical entity. Owing to high revision rates reported in young patients ranging between 18 and $48 \%$, reverse shoulder arthroplasty is considered the last-line treatment $[6,8,17,23]$. Thus, the general clinical goal is to delay arthroplasty for as long as possible. Many therapeutic options including debridement, long head of biceps tenotomy, partial rotator cuff repair, tendon transfer $[7,14$, 16], and subacromial spacer implantation $[12,28]$ have been proposed and performed with varying short- and often disappointing long-term results. Superior capsular reconstruction (SCR) was popularized by Mihata et al. [22] in 2012 to overcome superior humeral translational instability after massive rotator cuff tears. Originally, a fascia lata autograft harvested via a minimally invasive lateral approach from the ipsilateral side was used as a graft. Grafts with a thickness of $8 \mathrm{~mm}$ were initially used for the procedure [13]. In a biomechanical laboratory setting, it was shown that a significant reduction in superior humeral translation and an increase in subacromial distance could be achieved with reconstruction of the superior glenohumeral joint capsule, while these effects were enhanced by sideto-side suturing between the infraspinatus and the posterior margin of the graft $[20,21]$. These promising in vitro results were then confirmed in a clinical study showing relatively quick pain reduction, followed by a significant increase in range of motion [19].

Owing to the morbidity associated with harvesting of fascia lata autograft, a human dermal allograft patch was introduced to overcome donor-site morbidity. Recent publications showed similar promising short-term results with significant reduction in pain and restoration of function after 1 year [2, 4, 11, 25].

However, whether this technique may be indicated as a treatment option for patients with pseudoparalysis remains unclear. Thus, the objective of this study was to investigate the functional and radiological short-term outcome after arthroscopic SCR with a human dermal allograft for partially irreparable rotator cuff tears. Furthermore, differences in outcome between patients with and without limited shoulder function were analyzed.

\section{Patients and methods}

All patients with irreparable supraspinatus tendon tear and intact or repairable subscapularis and repairable or partially repairable infraspinatus (ISP) tendon, with reduced daily activity and persistent night pain without improvement after conservative treatment including physiotherapy, who presented at our clinic in 2016 were eligible for arthroscopic SCR. All patients with a magnetic resonance image (MRI)-verified rotator cuff tear with retraction of Grade 3 according to Patte et al. [24] were considered for inclusion in the present study. Patients with an intraoperatively irreparable supraspinatus tendon tear were ultimately included in the study. Exclusion criteria were patients with reparable supraspinatus tendon tears, irreparable infraspinatus tendon and/or subscapularis tendon tears, and cuff tear arthropathy (>Grade 2 Hamada; [10]). Patients were divided into two groups depending on their preoperative range of motion. Patients with forward flexion over $90^{\circ}$ were included into group 1 . Patients with a forward flexion of $90^{\circ}$ or below were considered as having pseudoparalysis and were assigned to group 2.

Of 45 initially enrolled patients, a reconstruction of the supraspinatus tear was possible in 24 patients, who were therefore excluded from the study, while 21 underwent arthroscopic SCR with a dermal allograft. The study was ap- 
Table 1 Patient' characteristics

\begin{tabular}{|c|c|c|c|c|}
\hline & $\begin{array}{l}\text { Total } \\
(n=21)\end{array}$ & $\begin{array}{l}\text { Forward flexion } \\
>90^{\circ} \\
(n=9)\end{array}$ & $\begin{array}{l}\text { Forward flexion } \\
\leq 90^{\circ} \\
(n=12)\end{array}$ & $p$ \\
\hline Age (years) & $\begin{array}{l}65.9 \pm 7.4 \\
(50-77)\end{array}$ & $67.2 \pm 5.9(57-75)$ & $64.8 \pm 8.4(50-77)$ & 0.475 \\
\hline Gender (female/male) & $14(67) / 7(33)$ & $7(78) / 2(22)$ & $7(58) / 5(42)$ & 0.642 \\
\hline $\begin{array}{l}\text { Shoulder side (right/ } \\
\text { left) }\end{array}$ & $18(86) / 3(14)$ & $9(100) / 0$ & $9(75) / 3(25)$ & 0.229 \\
\hline $\begin{array}{l}\text { Dominant arm involved } \\
\text { (yes/no) }\end{array}$ & $20(95) / 1(5)$ & $9(100) / 0$ & $11(92) / 1(8)$ & 0.999 \\
\hline $\begin{array}{l}\text { Smoker (non/ex/ } \\
\text { current) }\end{array}$ & $\begin{array}{l}14(67) / 2(9) / 5 \\
(24)\end{array}$ & $6(67) / 1(11) / 2(22)$ & $8(67) / 1(8) / 3(25)$ & 0.971 \\
\hline $\begin{array}{l}\text { Diabetes mellitus } \\
\text { (yes/no) }\end{array}$ & $2(10) / 19(90)$ & $1(11) / 8(89)$ & $1(8) / 11(92)$ & 0.999 \\
\hline Prior surgery (yes/no) & $7(33) / 14(67)$ & $1(11) / 8(89)$ & $6(50) / 6(50)$ & 0.159 \\
\hline \multicolumn{5}{|l|}{$R C$ tear characteristics } \\
\hline SSP tear & $3(14)$ & $1(12)$ & $2(17)$ & \multirow[t]{4}{*}{0.792} \\
\hline SSP + SSC tear & $1(5)$ & 0 & $1(8)$ & \\
\hline SSP + ISP tear & $8(38)$ & $4(44)$ & $4(33)$ & \\
\hline $\mathrm{SSP}+\mathrm{SSC}+\mathrm{ISP}$ tear & $9(43)$ & $4(44)$ & $5(42)$ & \\
\hline \multicolumn{5}{|l|}{$R C$ repair with $S C R$} \\
\hline Patch repair & $5(24)$ & $2(22)$ & $3(25)$ & \multirow[t]{4}{*}{0.969} \\
\hline Patch + SSC repair & $3(14)$ & $1(12)$ & $2(17)$ & \\
\hline Patch + ISP repair & $7(33)$ & $3(33)$ & $4(33)$ & \\
\hline $\begin{array}{l}\text { Patch + SSC + ISP } \\
\text { repair }\end{array}$ & $6(29)$ & $3(33)$ & $3(25)$ & \\
\hline $\begin{array}{l}\text { Revision surgery indi- } \\
\text { cated }\end{array}$ & $6(29)$ & $2(33)$ & $4(67)$ & 0.659 \\
\hline
\end{tabular}

proved by the institutional review board (201609_EK13). Informed consent was obtained from all patients.

\section{Surgical technique}

All surgical procedures were performed by the same surgeon. The surgical procedure has been described in detail in previous publications $[18,25]$. In short, the patient was operated on in the beach chair position starting with a standardized diagnostic arthroscopy. The long head of biceps tendon, if still present, was tenotomized at its origin. Subacromial soft tissue debridement and an acromioplasty were performed in all cases. If the subscapularis tendon showed a tear, an arthroscopic repair was performed. Repairable tears of the infraspinatus tendon were addressed with partial repairs in order to re-create the force couple between anterior and posterior rotator cuff. The

\section{Postoperative treatment and rehabilitation}

Postoperative treatment was standardized for all patients. After surgery, patients were immobilized in a sling for 6 weeks. Only passive mobilization exercises were allowed. Assistive and active physiotherapy were allowed after 6 weeks with no strengthening exercises or loadbearing for 12 weeks postoperatively.

\section{Radiological, clinical, and subjective assessment}

Magnetic resonance imaging of the shoulder was performed before and $11.6 \pm 0.6$ months (range, $11-13$ months) after arthroscopic SCR and images were evaluated by two orthopedic surgeons independently (M.E., P.H.). Evaluation of the MRI was performed in standardized fashion using frontal, parasagittal, and coronal axis slices on a 3-Tesla MRI unit. The Structural integrity of the SCR and repaired rotator cuff tendons was evaluated using Sugaya's MRI classification considering Grades 1, 2, and 3 as intact, and Grades 4 and 5 as re-torn [29]. Tendon retraction was graded according to Patte et al. [24] Clinical and subjective assessment was made at baseline as well as $4.2 \pm 1.5$ months (range, $3-7$ ) and 11.6 \pm 0.6 months (range, 11-13) postoperatively. Shoulder function was assessed using the total Constant score (CS) and its subgroups pain, activity of daily living (ADL), range of motion (ROM), and strength. Subjective evaluation included the American Shoulder and Elbow Surgeons score (ASES, 0-100 points) and the Simple Shoulder Test score (SST, 0-12 points). Additionally, outcome was compared between patients with (abduction and/or flexion of $90^{\circ}$ or below, group 1) and without (abduction and/or flexion over $90^{\circ}$, group 2) pseudoparalytic conditions [30]. An MRIverified rupture of the dermal graft was considered as a study endpoint (treatment failure). Complications occurring during the study period were recorded. 
Obere Extremität 2020 $15: 122-129$ https://doi.org/10.1007/s11678-019-0531-3

(c) The Author(s) 2019

M. Eigenschink $\cdot$ L. Pauzenberger · B. Laky $\cdot$ W. Anderl · R. C. Ostermann · P. R. Heuberer

\section{Arthroscopic superior capsular reconstruction using a human dermal allograft in patients with and without preoperative pseudoparalysis}

\section{Abstract}

Background. Massive irreparable rotator cuff tears (RCT) may cause severe functional impairment and pain as a result of loss of superior humeral stability. Reconstruction of the superior capsule (SCR) has been reported to restore glenohumeral stability and function. Objective. The purpose of this study was to investigate short-term functional and radiological outcome after arthroscopic SCR with a human dermal allograft for irreparable RCT.

Methods. In total, 21 patients (mean age 65.9 years, 50-77), who underwent arthroscopic SCR were prospectively enrolled in the present study. Magnetic resonance images (MRI) were obtained before and 12 months after surgery to evaluate graft survival. Functional and subjective outcome including the Constant score (CS), the American Shoulder and Elbow Surgeons score (ASES), and the Simple Shoulder Test (SST) was evaluated preoperatively as well as 3-6 and 12 months postoperatively and was compared between patients with and without preoperative pseudoparalysis. Complications were recorded.

Results. The MRI evaluation revealed intact grafts in $71.4 \%$ of patients 1 year postoperatively; these patients showed significant improvements from baseline to follow-up time points regarding the total CS and its subgroups pain, activity of living, range of motion, strength, ASES, and SST $(p<0.01)$. Pseudoparalysis was present in $57.1 \%$ of cases preoperatively, but was reversed in $100 \%$ of cases with intact graft at the 1-year followup. The outcome was similar between groups at final follow-up. Complications occurred in $29 \%$ (one infection, five graft failures) of patients and were indications for treatment with reverse shoulder arthroplasty. Conclusion. Arthroscopic SCR with a human dermal allograft in patients with irreparable RCT restored shoulder function and relieved pain in patients without and with preoperative pseudoparalysis.

\section{Keywords}

Pseudoparalysis · Superior capsular reconstruction · Massive cuff tear · Irreparable rotator cuff · Shoulder

\section{Arthroskopische superiore Kapselrekonstruktion mittels humanem dermalem Allograft bei Patienten mit und ohne präoperative Pseudoparalyse}

\section{Zusammenfassung}

Hintergrund. Irreparable Rotatorenmanschettenrupturen (RMR) können deutliche Schmerzen und Funktionsverlust aufgrund des Verlusts der superioren glenohumeralen Stabilität verursachen. Durch die Rekonstruktion der superioren Kapsel (SCR) wurden Stabilität und Funktion wiedererlangt. Fragestellung. Ziel der vorliegenden Studie war es, klinische und radiologische Kurzzeitergebnisse nach arthroskopischem SCR-Eingriff mit dermalem Allograft bei irreparabler RMR zu erfassen.

Material und Methoden. In diese Studie wurden 21 Patienten mit einem Durchschnittsalter von 65,9 Jahren eingeschlossen, bei denen eine arthroskopische SCR erfolgte. Zur GraftEvaluierung wurde eine Untersuchung mittels Magnetresonanztomographie (MRT) vor und 12 Monate nach der Operation durchgeführt.
Das funktionelle und das subjektive Ergebnis wurde mittels Constant Score (CS), American Shoulder and Elbow Surgeons Score (ASES) und dem Simple Shoulder Test (SST) vor, 3-6 Monate und 12 Monate nach der Operation evaluiert. Diese Parameter wurden zwischen Patienten mit und ohne präoperative Pseudoparalyse verglichen. Komplikationen wurden dokumentiert. Ergebnisse. Nach einem Jahr erwies sich in $71,5 \%$ der Fälle der Patch in der MRT als intakt, es trat eine signifikante Besserung im CS und dessen Untergruppen Schmerz, Bewegung und Kraft, im ASES und im SST auf $(p<0,01)$. Eine Pseudoparalyse zeigte sich bei $57,1 \%$ aller Patienten präoperativ, diese hatte sich bei allen Patienten mit intaktem Patch nach einem Jahr zurückgebildet. Das klinische Ergebnis war nach einem Jahr in beiden Gruppen vergleichbar. Komplikationen traten in $29 \%$ der Fälle auf (1 Infektion, 5 Patchversagen), bei diesen wurde die Indikation zur inversen Prothese gestellt.

Schlussfolgerung. Der arthroskopische SCR mit humanem dermalem Allograft bei Patienten mit irreparabler RMR zeigt eine funktionelle Verbesserung und Schmerzreduktion. Dies wurde sowohl für Patienten mit guter Funktion als auch für Patienten mit glenohumeraler Pseudoparalyse nachgewiesen.

\section{Schlüsselwörter}

Pseudoparalyse · Superiore Kapselrekonstruktion - Massenruptur - Irreparable Rotatorenmanschette $\cdot$ Schulter

\section{Statistical analysis}

Patient details are presented using descriptive statistics. The distribution of the data was assessed by visual inspection of histograms and the Kolmogorov-Smirnov test. Parametric data are presented as mean \pm standard deviation, nonparametric data as median and range in parenthesis, or as num- bers and percentages in parenthesis for categorical variables. Paired $t$ tests or nonparametric Wilcoxon signed-rank tests were used to compare parameters between two time points. Independent $t$ tests or nonparametric Mann-Whitney $U$ tests were used to compare continuous variables between two groups. Chisquare or Fisher's exact tests were performed to analyze categorical variables.
All comparative tests were two-tailed and the statistical significance level was set at $p<0.05$. Statistical analyses were performed using SPSS Statistics 23 (IBM $^{\circledR}$ Corporation, Armonk, NY, USA).

\section{Results}

Demographic data and surgical details of all patients treated with arthroscopic 

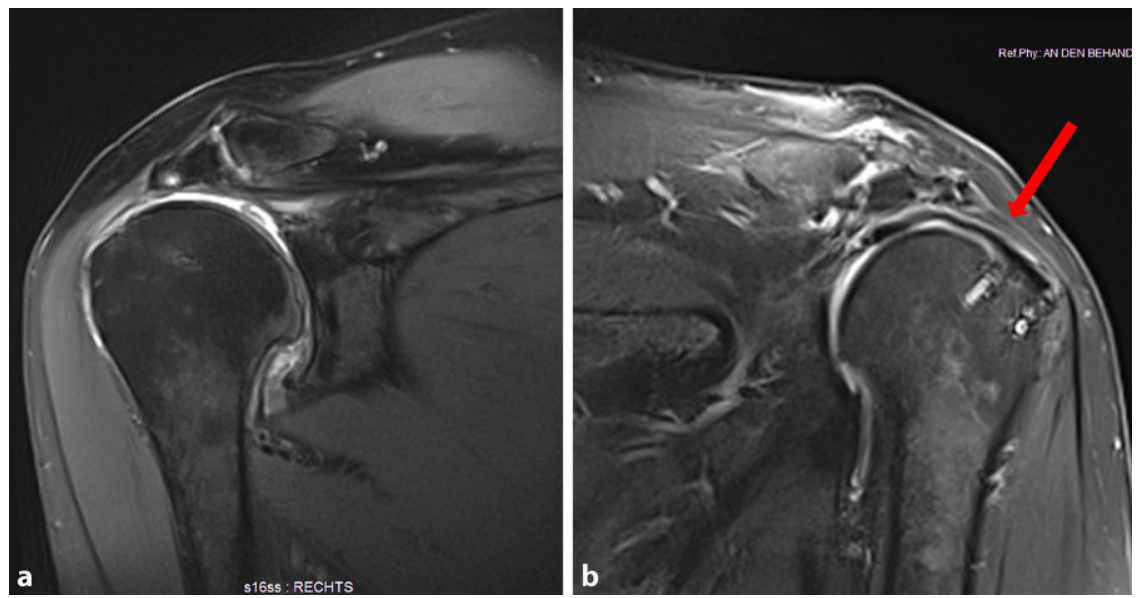

Fig. $1 \Delta$ Magnetic resonance imaging of the right shoulder showing total supraspinatus tear with retraction (a) and after arthroscopic superior capsular reconstruction with allograft patch fixated with suture anchors (arrow, b)
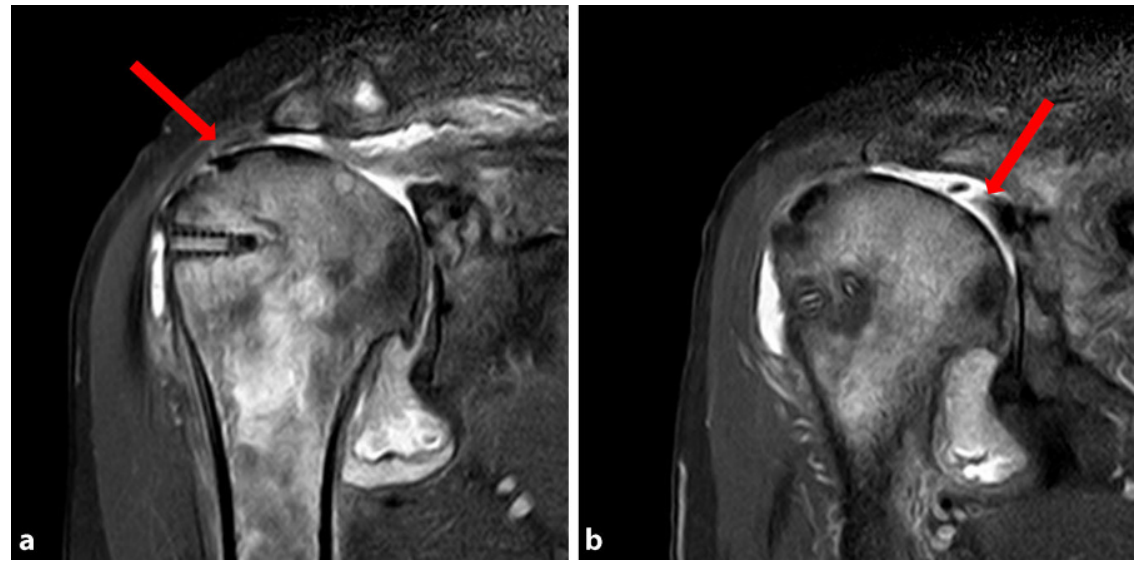

Fig. $2 \Delta$ Total allograft patch rupture: a rupture located on glenoidal side (arrow), b rupture located on humeral side (arrow)

SCR using a human dermal allograft are presented in $\bullet$ Table 1. Arthroscopic surgery prior to SCR included failed supraspinatus tendon reconstructions, latissimus dorsi transfer, debridement and long head of biceps tenotomy. No significant differences regarding demographic data were detected between patients with and without pseudoparalytic conditions ( $\bullet$ Table 1$)$. Tendon tears involving the musculus supraspinatus, infraspinatus, or subscapularis were detected and reported if reconstruction was needed. Preoperative radiographic evaluation according to the Hamada classification showed eight patients with Hamada Grade 1 and 13 shoulders with Hamada Grade 2. No significant difference in outcome or complications was detected.
The MRI evaluation revealed intact dermal grafts in 15 patients $(71.4 \%$; - Fig. 1). An MRI-verified rupture of the implanted graft was detected at $6.2 \pm 2.8$ months after SCR in six out of 21 cases $(28.4 \%$ total failure rate; location of the rupture in three cases at the humeral side and three at the glenoidal side, - Fig. 2). Revision surgery was performed on five patients (23.8\%) after a mean of $8.4 \pm 4.6$ months. Reverse total shoulder arthroplasty was performed in four cases: due to isolated graft failure with progressive cuff tear arthropathy in two cases, and graft failure with additional subscapularis rupture in the other two cases. In one case a low-grade infection (Cutibacterium acnes) resulting in graft failure led to subsequent revision surgeries (debridement and removal of all foreign materials followed by a planned reverse total shoulder arthroplasty). One additional patient with an isolated graft failure is scheduled to undergo reverse total shoulder arthroplasty.

Clinical and subjective evaluations of patients with intact grafts showed significant improvements from baseline to both postoperative time points regarding the CS including its subgroups pain, ADL, ROM and strength, ASES, SST, and the absolute ROMs in forward flexion and abduction (- Table 2). Comparisons between the first and second follow-up showed either constant or further improved outcome scores at the 12 -month timepoint (• Table 2).

Preoperative pseudoparalysis was present in 12 out of 21 cases (57.1\%). The majority of patients with SCR failure (four out of six patients, 66.7\%) presented with a preoperative pseudoparalysis including three patients with a forward flexion and/or abduction of less than $60^{\circ}$. The 3-6-month and 12-month followup revealed reversal of pseudoparalysis in 80 and $100 \%$ of patients (revisions not included), respectively (• Table 3 ).

Patients with pseudoparalysis compared with those without pseudoparalytic conditions showed significant baseline differences regarding total Constant scores and ASES (- Table 4). The SST was significantly better in the group without than in the group with pseudoparalysis at the 3-6-month follow-up (• Table 4). Regarding ROM, only the Constant score was significantly better at baseline and at the 3-6-month follow-up in the group without than in the group with shoulder function of $90^{\circ}$ or below, as shown in $\bullet$ Fig. 3. From the subgroup analysis, both groups overall showed significant improvement in forward flexion and abduction; for group 1 (forward flexion over $90^{\circ}$ ), the forward flexion was from 147 to $161^{\circ}$. For group 2, forward flexion of $90^{\circ}$ or below showed improvement for group $2 \mathrm{a}$ (forward flexion between 60 and $90^{\circ}$ ) from 74 to $155^{\circ}$ and for group $2 \mathrm{~b}$ (forward flexion below $60^{\circ}$ ) from 38 to $168^{\circ}$. 
Table 2 All scores before and after arthroscopic SCR with a human dermal allograft

\begin{tabular}{|c|c|c|c|c|c|c|}
\hline & Baseline & $\begin{array}{l}\text { 3-6 months } \\
\text { FU1 }\end{array}$ & $\begin{array}{l}12 \text { months } \\
\text { FU2 }\end{array}$ & $\begin{array}{l}p \\
\text { (baseline } \\
\text { vs. FU1) }\end{array}$ & $\begin{array}{l}p \\
\text { (baseline } \\
\text { vs. FU2) }\end{array}$ & $\begin{array}{l}p \\
\text { (FU1 } \\
\text { vs. FU2) }\end{array}$ \\
\hline CS Total & $30.3 \pm 15.3$ & $61.9 \pm 15.1$ & $77.3 \pm 15.2$ & $<0.001$ & $<0.001$ & 0.004 \\
\hline CS pain & $5(0-5)$ & $10(5-15)$ & $15(10-15)$ & 0.001 & 0.001 & 0.025 \\
\hline CS ADL & $6(2-17)$ & $14(9-28)$ & $18(8-28)$ & 0.001 & 0.001 & 0.029 \\
\hline CS ROM & $16(4-38)$ & $26(18-40)$ & $36(22-40)$ & 0.016 & 0.001 & 0.005 \\
\hline CS strength & $0(0-6)$ & $10(2-20)$ & $10(0-25)$ & 0.002 & 0.001 & 0.172 \\
\hline \multicolumn{7}{|l|}{$R O M$} \\
\hline $\mathrm{FF}$ & $100(45-170)$ & $150(90-170)$ & 165 (120-170) & 0.031 & 0.003 & 0.025 \\
\hline ABD & $90(30-175)$ & $150(80-180)$ & $170(90-180)$ & 0.018 & 0.005 & 0.027 \\
\hline ASES & $34.0 \pm 12.6$ & $67.1 \pm 20.3$ & $82.0 \pm 16.7$ & $<0.001$ & $<0.001$ & 0.003 \\
\hline SST & $2.4 \pm 2.4$ & $8.0 \pm 3.1$ & $8.5 \pm 3.3$ & $<0.001$ & $<0.001$ & 0.481 \\
\hline
\end{tabular}

Table 4 Comparison of scores between patients with and without pseudoparalysis

\begin{tabular}{|c|c|c|c|}
\hline & $\begin{array}{l}\text { Forward flexion }>90^{\circ} \\
(n=7)\end{array}$ & $\begin{array}{l}\text { Forward flexion } \leq 90^{\circ} \\
(n=8)\end{array}$ & $p$ \\
\hline \multicolumn{4}{|l|}{ CS Total } \\
\hline Baseline & $40.7 \pm 16.2$ & $21.1 \pm 6.4$ & 0.018 \\
\hline $3-6$ months & $68.0 \pm 13.8$ & $56.5 \pm 15.0$ & 0.148 \\
\hline 12 months & $76.0 \pm 18.3$ & $78.4 \pm 13.2$ & 0.776 \\
\hline \multicolumn{4}{|l|}{ ASES } \\
\hline Baseline & $41.0 \pm 14.7$ & $27.9 \pm 6.5$ & 0.041 \\
\hline $3-6$ months & $76.7 \pm 15.5$ & $58.8 \pm 21.1$ & 0.087 \\
\hline 12 months & $84.3 \pm 18.4$ & $80.0 \pm 16.1$ & 0.638 \\
\hline \multicolumn{4}{|l|}{ SST } \\
\hline Baseline & $3.3 \pm 2.9$ & $1.6 \pm 1.8$ & 0.222 \\
\hline $3-6$ months & $10.3 \pm 1.7$ & $6.0 \pm 2.6$ & 0.002 \\
\hline 12 months & $9.3 \pm 3.1$ & $7.9 \pm 3.5$ & 0.428 \\
\hline
\end{tabular}

\section{Discussion}

The most important finding of the present study was that SCR with an acellular human dermal allograft could be confirmed to be a valid short-term option to restore shoulder function in patients with irreparable supraspinatus tendon tears with or without repairable subscapularis or infraspinatus and limitation in shoulder function. However, there was a relatively high revision rate in the short term that has to be considered when performing SCR.

After 3-6 months, $80 \%$ of patients with pseudoparalysis regained a significant part of their shoulder function. This rate further increased to $100 \%$ at the 12 month mark. Burkhart et al. [1] were able to show similar results for SCR in patients with pseudoparalysis and irreparable rotator cuff tear with reproducible reversal of pseudoparalysis in $90 \%$ of the cases compared with a significantly lower rate of $44 \%$ following partial repairs. Mihata et al. [18] showed significant improvement in range of motion from 54.3 to $146.8^{\circ}$ for patients with moderate $\left(<90^{\circ}\right.$ forward flexion) and from 36.7 to $150.0^{\circ}$ for patients with severe pseudoparalysis $\left(<45^{\circ}\right.$ forward flexion). This is comparable to our results using a dermal allograft, which provided improvement of forward flexion from 74 to $155^{\circ}$ in moderate and from 38 to $168^{\circ}$ in severe pseudoparalysis, respectively. In our non-pseudoparalysis group $\left(>90^{\circ}\right.$ forward flexion) forward flexion improved from 147 to $161^{\circ}$, which
Table 3 Number of patients with and

without pseudoparalysis at baseline and

postoperatively after arthroscopic SCR with

a human dermal allograft

\begin{tabular}{|c|c|c|c|}
\hline & $\begin{array}{l}\text { Mild lim- } \\
\text { itation in } \\
\text { shoulder } \\
\text { function } \\
\left(180-91^{\circ}\right)\end{array}$ & $\begin{array}{l}\text { Limita- } \\
\text { tion in } \\
\text { shoul- } \\
\text { der } \\
\text { function } \\
\left(90-61^{\circ}\right)\end{array}$ & $\begin{array}{l}\text { Severe } \\
\text { limita- } \\
\text { tion in } \\
\text { shoulder } \\
\text { function } \\
\left(\leq 60^{\circ}\right)\end{array}$ \\
\hline Baseline & 7 & 4 & 4 \\
\hline $\begin{array}{l}3-6 \\
\text { months }\end{array}$ & 12 & 3 & 0 \\
\hline $\begin{array}{l}12 \\
\text { months }\end{array}$ & 15 & 0 & 0 \\
\hline$S C R$ sup & erior capsular & nstru & \\
\hline
\end{tabular}

is similar to results of a recent study reporting 1-year improvements for forward flexion from 120 to $160^{\circ}$ [25].

Despite range of motion and function often being the focus of attention, pain relief remains an important factor for improving a patient's quality of life and performance of common daily activities. The present study found a significant, swift pain reduction in the first 3-6 months after surgery, which is in line with recent publications showing similar pain reduction from the pre- to postoperative period $[1,4,5,25]$. Furthermore, it has to be confirmed in long-term studies whether SCR prevents or, at a minimum, leads to clinically significant delays in the progression of cuff tear arthropathy. The use of an Inspace balloon remains controversial; recent studies showed an initial significant improvement but higher complication rates after 1 year of followup [12, 28]. Clinical studies with longer follow-up and improved implant systems are needed.

Similar to our study, four recent publications about SCR with human dermal allografts reported failure rates between 40 and $60 \%$ with mainly humeral side ruptures $[4,11,15,25]$, while recent data on SCR with fascia lata autografts described failure rates between 5 and $10 \%[3,18]$. Although the literature on SCR with fascia lata is limited, the healing rate of autografts seems to be far better. The same is known for anterior cruciate ligament reconstruction where the use of allografts is known to be safe, but can be associated with a significantly higher failure 

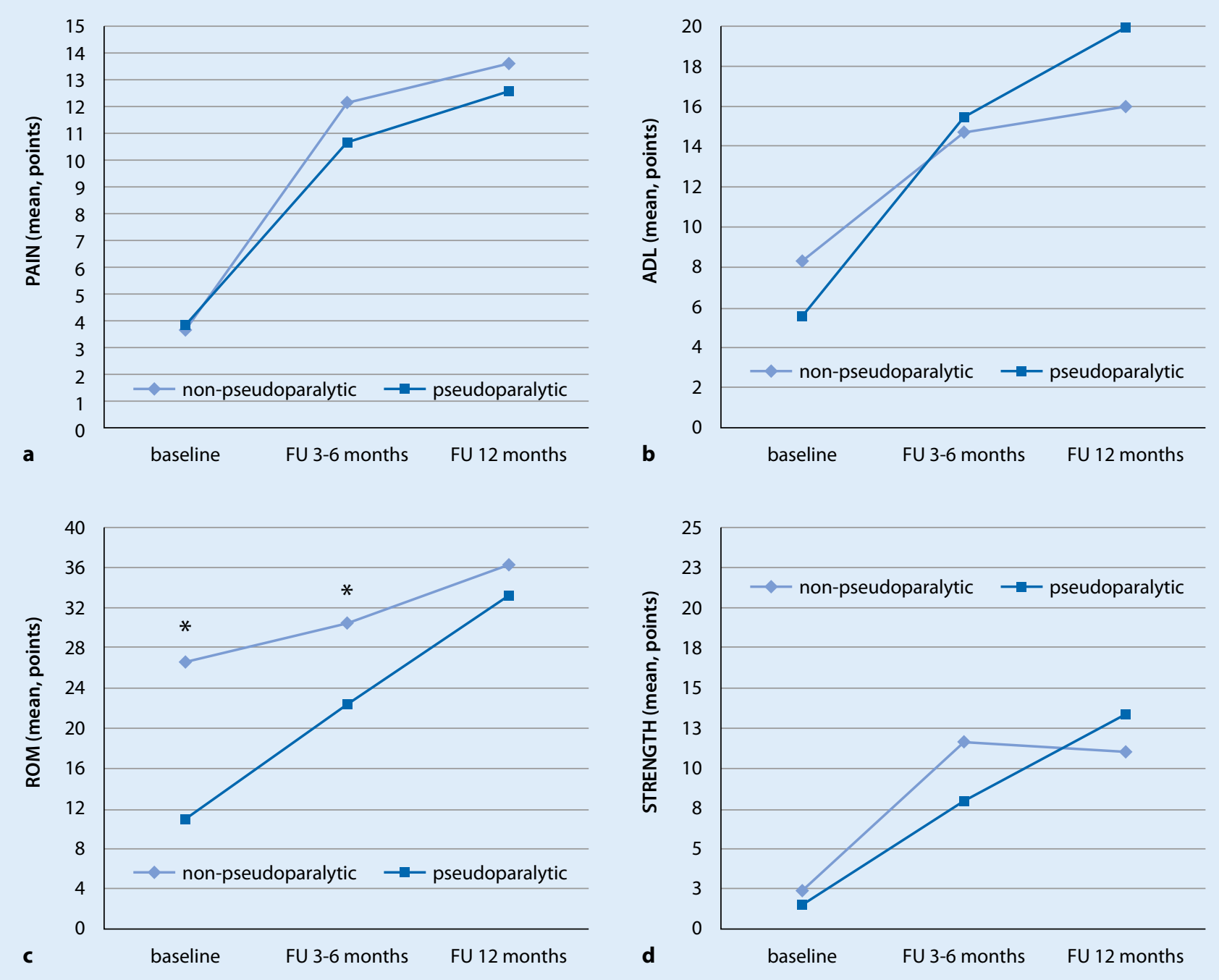

Fig. 3 A Illustration of the mean Constant Score subgroups a pain, b activities of daily living $(A D L), \mathbf{c}$ range of motion $(R O M)$, and $\mathbf{d}$ strength at baseline and at the 3-6-and 12-month follow-up (FU). Asterisks show significant $(p<0.05)$ differences between patients with and without preoperative pseudoparalytic conditions

and reoperation rate and postoperative stability $[2,9,31]$. Allograft incorporation to host tissue, which can be up to 1 year, takes much longer compared with autografts [5]. However, when using autografts, donor site morbidity, especially when taking a long fascia lata graft, needs to be considered. In fact, Azevedo et al. [3] reported that at the 2-year follow-up, $57 \%$ of patients were still bothered by their harvested thigh and $76 \%$ noticed donor site changes.

However, Plachel et al. [26, 27] in their case report showed that there is ingrowth of vessels and expression of growth factors in the acellular human dermal allograft patch after 6 months, which led them to the conclusion that healing of the graft to the native tissue may be facilitated. However, in their histologic samples they only analyzed soft tissue and not the patch-bone interface, which is crucial for the construct to survive.

Another detail complicating comparisons between autograft and allograft SCR is that to date most studies using allografts started with a preoperatively better shoulder function than the studies using autografts $[6,27]$. Further definitions of the criteria for the indication for SCR still need to be developed to help decide who will benefit the most from the procedure. Moreover, irreparability of rotator cuff tears is very much surgeon dependent. In our 45 patients who had been initially scheduled for SCR based on history, ex- amination, and preoperative MRI, more than half turned out to have repairable rotator cuff tears with extensive release techniques.

As shown in a current publication, cuff tear arthropathy at time of surgery remains a limiting factor for expected outcomes. Denard et al. reported differences in success rates of $75 \%$ for Hamada Grades 1-2 and 44\% for Hamada Grades 3-4. However, our finding together with those from recent publications present promising short- to mid-term results after SCR in patients with irreparable posterosuperior rotator cuff tear under appearance of severe loss in range of motion. Long-term results on consistent regain of function and 
Table 5 Study details of reported arthroscopic superior capsular reconstruction with auto- and allografts

\begin{tabular}{|c|c|c|c|c|c|c|}
\hline Publication & $\begin{array}{l}\text { Graft } \\
\text { type }\end{array}$ & $N$ & $\begin{array}{l}\text { FU } \\
\text { (in } \\
\text { years) }\end{array}$ & $\begin{array}{l}\text { Clinical outcome } \\
\text { (pre- to postoper- } \\
\text { ative) }\end{array}$ & $\begin{array}{l}\text { ROM } \\
\text { (pre- to postoper- } \\
\text { ative) }\end{array}$ & $\begin{array}{l}\text { Healing } \\
\text { rate [\%] }\end{array}$ \\
\hline $\begin{array}{l}\text { Mihata et al. [18] } \\
\text { Arthroscopy } 2013\end{array}$ & $\begin{array}{l}\text { Fascia } \\
\text { lata }\end{array}$ & 24 & $2-4$ & ASES: $24 \rightarrow 93$ & $84^{\circ} \rightarrow 148^{\circ}$ & 83 \\
\hline $\begin{array}{l}\text { Mihata et al. [17] } \\
\text { AmJSM } 2018\end{array}$ & $\begin{array}{l}\text { Fascia } \\
\text { lata }\end{array}$ & 88 & $3-9$ & $\begin{array}{l}\text { ASES: }(44, \\
29,20) \rightarrow \\
(97,92,92)\end{array}$ & $\begin{array}{l}\left(143^{\circ}, 54^{\circ}, 37^{\circ}\right) \rightarrow \\
\left(164^{\circ}, 147^{\circ}, 150^{\circ}\right)\end{array}$ & 92 \\
\hline $\begin{array}{l}\text { Azevedo et al. [3] } \\
\text { OJSM } 2018\end{array}$ & $\begin{array}{l}\text { Fascia } \\
\text { lata }\end{array}$ & 22 & 2 & CS: $18 \rightarrow 65$ & $75^{\circ} \rightarrow 144^{\circ}$ & 91 \\
\hline $\begin{array}{l}\text { Pennington et al. } \\
\text { [24] } \\
\text { Arthroscopy } 2018\end{array}$ & $\begin{array}{l}\text { Allo- } \\
\text { graft }\end{array}$ & 86 & 1 & ASES: $52 \rightarrow 82$ & $120^{\circ} \rightarrow 160^{\circ}$ & 95 \\
\hline $\begin{array}{l}\text { Denard et al. [4] } \\
\text { Arthroscopy } 2018\end{array}$ & $\begin{array}{l}\text { Allo- } \\
\text { graft }\end{array}$ & 59 & 1 & ASES: $44 \rightarrow 78$ & $130^{\circ} \rightarrow 150^{\circ}$ & $45(75)$ \\
\hline $\begin{array}{l}\text { Burkhart and } \\
\text { Hartzler [1] } \\
\text { Arthroscopy } 2018\end{array}$ & $\begin{array}{l}\text { Allo- } \\
\text { graft }\end{array}$ & 10 & 1 & ASES: $52 \rightarrow 89$ & $27^{\circ} \rightarrow 159^{\circ}$ & 70 \\
\hline $\begin{array}{l}\text { Lee and Min [15] } \\
\text { KSSTA } 2018\end{array}$ & $\begin{array}{l}\text { Allo- } \\
\text { graft }\end{array}$ & 36 & 2 & $\begin{array}{l}\text { ASES: } 50 \rightarrow 84 \\
\text { CS: } 56 \rightarrow 83\end{array}$ & $\begin{array}{l}107^{\circ}+158^{\circ} \rightarrow \\
156^{\circ}+135^{\circ}\end{array}$ & 64 \\
\hline $\begin{array}{l}\text { Hirahara et al. [10] } \\
\text { AJO2019 }\end{array}$ & $\begin{array}{l}\text { Allo- } \\
\text { graft }\end{array}$ & 9 & 2 & ASES: $42 \rightarrow 87$ & $x$ & $80(4 / 5)$ \\
\hline Present study & $\begin{array}{l}\text { Allo- } \\
\text { graft }\end{array}$ & 21 & 1 & $\begin{array}{l}\text { ASES: } 34(41,28) \rightarrow \\
82(84,80) \\
\text { CS: } 30(41,21) \rightarrow \\
77(76,78)\end{array}$ & $\begin{array}{l}\text { FF: } 107^{\circ} \\
\left(147^{\circ}, 72^{\circ}\right) \rightarrow \\
161^{\circ}\left(161^{\circ}, 161^{\circ}\right) \\
\text { ABD: } 100^{\circ} \\
\left(144^{\circ}, 63^{\circ}\right) \rightarrow \\
156^{\circ}\left(156,156^{\circ}\right)\end{array}$ & 71 \\
\hline \multicolumn{7}{|c|}{$\begin{array}{l}A B D \text { abduction, ASES American Shoulder and Elbow Surgeons score CS Constant score, FF forward } \\
\text { flexion, FU follow-up, ROM range of motion }\end{array}$} \\
\hline
\end{tabular}

reports of prolonging the appearance of osteoarthritis are needed to prove the sustained longevity of this surgical treatment option.

The term "pseudoparalysis" as a clinically described condition of limited shoulder function remains not clearly defined. Tokish et al. performed a systematic review and found a wide use of the term "pseudoparalysis" describing clinical shoulder function, reaching from "below 90 degrees in forward flexion" to massive limitation of shoulder function with cranialization of the humeral head with ventral subluxation [1, 30]. First of all, a clinical definition of severe shoulder dysfunction as suggested by the term "pseudoparalysis" should be given and pain as a causing factor needs to be excluded. Secondly, the biomechanical principle needs to be clarified regarding whether the superior capsule is the main restraint against anterosuperior glenohumeral escape or whether rotator cuff failure is responsible. We recommend a more precise use and a clearer definition of this clinical presentation and its pathology.

In summary, we confirmed that SCR for irreparable rotator cuff tears shows promising results especially if the graft healed successfully; however, it should remain a treatment option reserved for the specialist shoulder surgeon to optimize outcomes and minimize failures. Moderate-to-severe pseudoparalysis does not seem to represent a contraindication for SCR according to this and other recently published studies (• Table 5; [1, 3, 4, 15, 18, 19, 25]). For patients with irreparable rotator cuff tear with no or mild arthritis, SCR seems to have the potential to become a valuable tool in the armamentarium of shoulder surgeons; however, long-term results are required to judge the true benefits of the procedure.

\section{Limitations}

The primary limitations of this study are the short follow-up period and the low number of enrolled patients. Furthermore, comparisons between other jointpreserving techniques such as debridement, partial rotator cuff repair, or tendon transfers and superior capsular reconstruction should be performed in the future.

\section{Practical conclusion}

\section{- Superior capsular reconstruction (SCR) is a promising option for the treatment of irreparable rotator cuff tears in patients with no or mild osteoarthritis. \\ - The technique reproducibly provided early reduction of pain and restora- tion of shoulder function in patients with and without pseudoparalysis. \\ - However, the short-term revision rate was relatively high, which has to be considered when performing SCR.}

\section{Corresponding address}

Dr. Philipp R. Heuberer, MD
Health Pi
Wollzeile 1-3, 1010 Vienna,
Austria
philipp@heuberer.at

Funding. This study was supported by the Austrian Research Group for Regenerative and Orthopedic Medicine (AURROM), Vienna, Austria Research project $2018 \mathrm{~V}-078$.

Author Contribution. All authors made substantive intellectual contributions to the study. The authors' responsibilities were as follows: P.R. Heuberer, L. Pauzenberger, and W. Anderl initiated the study regarding conception and design; $M$. Eigenschink and R.C. Ostermann collected data and performed the literature search, B. Laky and M. Eigenschink performed statistical analysis, P.R. Heuberer and W. Anderl supervised the conduction of the study; all authors were actively involved in drafting the manuscript or revising it critically for important intellectual content, and have given final approval of the version to be published. 


\section{Compliance with ethical guidelines}

Conflict of interest W. Anderl, R.C. Ostermann, and P.R. Heuberer receive personal fees from Arthrex, Inc. The company had no influence on the study design, data collection, interpretation of the results, or the final manuscript. The remaining authors (M. Eigenschink, L. Pauzenberger, B. Laky) declare that they do not have any conflicts of interest pertinent to this study.

The study was approved by the institutional review board (201609_EK13) and all investigations were accomplished regarding national law and the declaration of Helsinki 1975 (revised version). Informed consent was obtained from all patients.

Open Access. This article is distributed under the terms of the Creative Commons Attribution 4.0 International License (http://creativecommons.org/licenses/by/ 4.0/), which permits unrestricted use, distribution, and reproduction in any medium, provided you give appropriate credit to the original author(s) and the source, provide a link to the Creative Commons license, and indicate if changes were made.

\section{References}

1. Burkhart SS, Hartzler RU (2019) Superior capsular reconstruction reverses profound pseudoparalysis in patients with irreparable rotator cuff tears and minimal or no Glenohumeral arthritis. Arthroscopy 35:22-28

2. Condello V, Zdanowicz U, Di Matteo B et al (2019) Allograft tendons are a safe and effective option for revision ACL reconstruction: a clinical review. Knee Surg Sports Traumatol Arthrosc 27(6):1771-1781. https://doi.org/10.1007/s00167-018-5147-4

3. De Campos Azevedo Cl, Angelo A, Vinga S (2018) Arthroscopic superior capsular reconstruction with a minimally invasive harvested fascia Lata Autograft produces good clinical results. Orthop J Sports Med 6:2325967118808242

4. Denard PJ, Brady PC, Adams CR et al (2018) Preliminary results of Arthroscopic superior capsule reconstruction with dermal Allograft. Arthroscopy 34:93-99

5. Eagan MJ, Mcallister DR (2009) Biology of allograft incorporation. Clin Sports Med 28:203-214 (vii)

6. Ek ET, Neukom L, Catanzaro S et al (2013) Reverse total shoulder arthroplasty for massive irreparable rotator cuff tears in patients younger than 65 years old: results after five to fifteen years. J Shoulder Elbow Surg 22:1199-1208

7. El-Azab HM, Rott O, Irlenbusch U (2015) Longterm follow-up after latissimus dorsi transfer for irreparable posterosuperior rotator cuff tears. J Bone Joint Surg Am 97:462-469

8. Familiari F, Rojas J, Nedim Doral M et al (2018) Reverse total shoulder arthroplasty. EFORT Open Rev 3:58-69

9. Grassi A, Nitri M, Moulton SG et al (2017) Does the type of graft affect the outcome of revision anterior cruciate ligament reconstruction? a meta-analysis of 32 studies. Bone Joint J 99-B:714-723

10. Hamada KFH, Mikasa M, Kobayashi Y (1990) Roentgenographic findings in massive rotator cuff tears A long-term observation. Clin Orthop Relat Res 254:92-96
11. Hirahara AM, Andersen WJ, Panero AJ (2017) Superior capsular reconstruction: clinical outcomes after minimum 2-year follow-up. Am J Orthop (Belle Mead, NJ) 46:266-278

12. Holschen M, Brand F, Agneskirchner JD (2017) Subacromial spacer implantation for massive rotator cuff tears: Clinical outcome of arthroscopically treated patients. Obere Extremität 12:38-45

13. Ishihara Y, Mihata T, Tamboli M et al (2014) Role of the superior shoulder capsule in passive stability of the glenohumeral joint. J Shoulder Elbow Surg 23:642-648

14. Klinger HM, Spahn G, Baums MH et al (2005) Arthroscopic debridement of irreparable massive rotator cuff tears-a comparison of debridement alone and combined procedure with biceps tenotomy. Acta Chir Belg 105:297-301

15. Lee SJ, Min YK (2018) Can inadequate acromiohumeral distance improvement and poor posterior remnant tissue be the predictive factors of retear? Preliminary outcomes of arthroscopic superior capsular reconstruction. Knee Surg Sports Traumatol Arthrosc 26:2205-2213

16. Ling HY, Angeles JG, Horodyski MB (2009) Biomechanics of latissimus dorsi transfer for irreparable posterosuperior rotator cuff tears. Clin Biomech (Bristol, Avon) 24:261-266

17. Merolla G, Porcellini G (2014) Reverse shoulder Arthroplasty in patients aged sixty years old or younger: are we really doing the best? Transl Med UniSa 9:66-67

18. Mihata T, Lee TQ, Hasegawa A et al (2018) Arthroscopic superior capsule reconstruction can eliminate pseudoparalysis in patients with irreparable rotator cuff tears. Am J Sports Med 46:2707-2716

19. Mihata T, Lee TQ, Watanabe $C$ et al (2013) Clinical results of arthroscopic superior capsule reconstruction for irreparable rotator cuff tears. Arthroscopy 29:459-470

20. Mihata T, Mcgarry MH, Kahn T et al (2016) Biomechanical effect of thickness and tension of fascia Lata graft on Glenohumeral stability for superior capsule reconstruction in irreparable Supraspinatus tears. Arthroscopy 32:418-426

21. Mihata T, Mcgarry MH, Kahn T et al (2016) Biomechanical role of capsular continuity in superior capsule reconstruction for irreparable tears of the Supraspinatus tendon. Am J Sports Med 44:1423-1430

22. Mihata T, Mcgarry MH, Pirolo JM et al (2012) Superior capsule reconstruction to restore superior stability in irreparable rotator cuff tears: a biomechanical cadaveric study. Am J Sports Med 40:2248-2255

23. Muh SJ, Streit JJ, Wanner JP et al (2013) Early follow-up of reverse total shoulder arthroplasty in patients sixty years of age or younger. J Bone Joint Surg Am 95:1877-1883

24. Patte $D$ (1990) Classification of rotator cuff lesions Clin Orthop Relat Res. https://doi.org/10.1097/ 00003086-199005000-00012

25. Pennington WT, Bartz BA, Pauli JM et al (2018) Arthroscopic superior capsular reconstruction with Acellular dermal Allograft for the treatment of massive irreparable rotator cuff tears: short-term clinical outcomes and the radiographic parameter of superior capsular distance. Arthroscopy 34:1764-1773

26. Plachel $F$, Klatte-Schulz $F$, Minkus $M$ et al (2018) Biological allograft healing after superior capsule reconstruction. J Shoulder Elbow Surg 27:e387-e392
27. Plachel F, Minkus M, Scheibel M (2018) Superiore Kapselrekonstruktion: Indikation und klinische Resultate. Obere Extremität 13:237-245

28. Singh JA, Sperling J, Buchbinder R et al (2011) Surgery for shoulder osteoarthritis: a Cochrane systematic review. JRheumatol 38:598-605

29. Sugaya HMK, Matsuki K, Moriishi J (2007) Repair integrity and functional outcome after arthroscopic double-row rotator cuff repair. A prospective outcome study. J Bone Joint Surg Am 89:953-960

30. Tokish JM, Alexander TC, Kissenberth MJ et al (2017) Pseudoparalysis: a systematic review of term definitions, treatment approaches, and outcomes of management techniques. J Shoulder Elbow Surg 26:e177-e187

31. Wang HD, Zhang $H$, Wang TR et al (2018) Comparison of clinical outcomes after anterior cruciate ligament reconstruction with hamstring tendon autograft versus soft-tissue allograft: a meta-analysis of randomised controlled trials. Int J Surg 56:174-183 